\title{
Pastoral Care as the Church's Response to the Phenomenon of Secularization
}

\author{
DARIUSz LIPIEC* \\ - https://doi.org/10.31823/d.28.1.5 • \\ UDC: $272-48 * 299.5(4) \cdot$ Review article \\ Recieved: 22. january 2019. • Accepted: 11. february 2020.
}

* Dariusz Lipiec,

Prof., Dr. habil., The John Paul II Catholic

University of Lublin,

Al. Racławickie 14, 20-950 Lublin, Poland, dlipiec@kul.pl

Summary: The ongoing process of the secularization of European societies has been present for a few decades now. It is a great challenge for the Church who is trying to resist it in a variety of ways. Pastoral care, meant as the organized saving activity of the Church aimed at saving the man, is one such way. However, resisting the process of secularization is not the direct goal of pastoral care. If pastoral care is run in a proper way, it can be a powerful and meaningful tool of the Church in resisting laicization. The article presents various forms of ordinary and extraordinary pastoral care which contribute to the development of religiousness of believers and to spreading the Gospel in the common social life. The author first presents the role of ordinary pastoral care in this process. He then lists proclaiming God's word, various forms of the cult and the ministry of Christian love as ways of reviving religious life. He also indicates the role of extraordinary pastoral care, especially the branch which aims at the cooperation with new developing working groups and other informal secular associations.

Keywords: the Church, secularization, laicization, pastoral care, ordinary pastoral care, extraordinary pastoral care.

\section{Introduction}

The ongoing social and cultural pluralism in the European and American civilization, also noticeable in Poland in the past decades, is strongly connected with the phenomenon 
of secularization ${ }^{1}$. Although the phenomenon has various descriptions, it is still not easy to define. The name $\gg$ secularization $\ll$ is similar to the concepts of laicisation, de-Christianization, liberation from the ecclesiastical control or desacralization. We can assume that secularization is $\gg$ the process which leads to the independence of the social life and its institution from the influence of religion and the Churches (...). In religious sphere it leads to the downfall of ecclesial religiosity and to the development of various forms of secular activities as well as to seeking the sacred outside the official structures of the Churches or outside religion (...). As a result of secularization, religion is pushed away from the public to the private sphere, which further leads to privatization and individualization of religious life $\ll^{2}$. For the Church whose mission is strongly connected with saving the man and building God's Kingdom on earth, the phenomenon of secularization is a challenge which requires a response ${ }^{3}$.

Pastoral care is an exemplary response to the process of secularization. Pastoral care is $\gg$ the organized saving activity of the Church which reflects the saving activity of Christ in the service of man, in proclaiming the word of God, in liturgy, in the pastoral ministry and in the testimony of the Christian life. In contemporary times pastoral care comes in two varieties: ordinary and extraordinary $\ll^{4}$. Pastoral care was created mainly as a service for the members of the Church in order to help them maintain their deep faith in God and their relationship with Him, through sacraments and prayer. It also maintains and develops the unity between the members through the practise of brotherly Christian love. Furthermore, it is a valuable way of building God's Kingdom on earth. And although preventing secularization is not one of the main goals of pastoral care, it serves the purpose perfectly, in a direct and indirect way. It is manifested in a direct way in its impact on non-believers or those who distanced themselves from the Church because such people rarely take part in any religious rituals or any celebrations organized by the Church. The indirect impact of pastoral care prevents secularization as it gives strength to believers to protect them from secularization. It should also be noticed that pastoral care manifests the Church's missionary ministry as it is addressed to non-believers and to those who distanced themselves from the Church.

\footnotetext{
${ }^{1}$ Wiesław Śmigiel, »Nowa ewangelizacja wyzwaniem dla Kościoła w Polsce, « in Roczniki Teologiczne, 56 (2014) no. 6, pp. 52-53.

${ }^{2}$ Marek Marczewski, Janusz Mariański, »Sekularyzacja,« in: Encyklopedia katolicka, vol. 17, col. 1374.

${ }^{3}$ Kazimierz Święs, »Aktualny kontekst społeczno-kulturowy jako zagrożenie dla wiary,« in: Duszpasterstwo wobec kryzysu wiary, ed. Wiesław Przygoda, (Lublin: Wydawnictwo KUL, 2013), pp. 57-58.

${ }^{4}$ Ryszard Kamiński, Wiesław Przygoda, »Duszpasterstwo,« in: Leksykon teologii pastoralnej, ed. Ryszard Kamiński, Wiesław Przygoda, Marek Fiałkowski, (Lublin: TN KUL, 2006), p. 201.
} 


\section{Ordinary Pastoral Care as a Response to the Phenomenon of Secularization}

Ordinary pastoral care is $\gg$ the organized saving activity of the Church which aims at all the faithful and which directly seeks to satisfy their religious needs and to achieve the aim of the Church and of every religious community which is to realize an encounter with God in faith and love $\ll^{5}$. This is the main role of pastoral care, which makes it the main agent to implement the saving mission of the Church. It is realized through the proclaiming of God's word, through liturgy and through the service of Christian love.

\subsection{Proclaiming the Word of God}

Proclaiming God's word has many different functions in the pastoral ministry of the Church and in the lives of those to whom it is addressed. First, it delivers information about God and about the supernatural reality connected with Him. It also has a formative function as it influences and forms the recipients and their life attitudes. What is more, it influences the life of the community of the listeners of God's word, and shapes the civilization which they create. Proclaiming God's word always leads to a personal and individual encounter with God and strengthens our relationship with $\mathrm{Him}^{6}$.

In contemporary times of the ongoing secularization, the Church must take up the task of pre-evangelization to make the faithful interested in the matters concerning God and to prepare them to properly receive the Good News ${ }^{7}$. Scientific research indicates that in Poland, apart from those who declare themselves as believers or as those who deeply believe, there are people who declare themselves as non-believers or who dissociate themselves from the Church ${ }^{8}$. The weakening or breaking of their relationship with God and with the Church is often the result of the lack of proper knowledge concerning the supernatural reality or the fact of acquiring this knowledge mainly from the secular media. Most of the mainstream media coverage

\footnotetext{
${ }^{5}$ Ryszard Kamiński, »Duszpasterstwo zwyczajne, « in Leksykon teologii pastoralnej, p. 212.

${ }^{6}$ Ryszard Kamiński, Działalność zbawcza Kościoła $w$ teorii i praktyce pastoralnej, (Lublin: Wydawnictwo KUL, 2007), pp. 230-240.

${ }^{7}$ Wiesław Przygoda, »Preewangelizacja - ekstrawagancja czy pastoralna konieczność?,« in Peryferie wiary wyzwaniem dla Kościoła, ed. Wiesław Przygoda, Marek Fiałkowski, (Lublin: Wydawnictwo KUL, 2015), pp. 22-26.

${ }^{8}$ Bogusław Drożdż, »Uwarunkowania społeczno-kulturowe ewangelizacji w Polsce na początku XXI wieku, « in Ewangelizacja odpowiedzią Kościoła w Polsce na wyzwania wspótczesności, ed. Wiesław Przygoda, Edmund Robek, (Sandomierz: Wydawnictwo Diecezjalne i Drukarnia w Sandomierzu, 2011), pp. 43-46.
} 
is often negative towards religion and in particular to the Catholic Church. The way information is chosen and presented is often such to arouse negative associations with religion in the recipients and to cause them to distance themselves from the institutions and people connected with religion?.

It should also be noted that this encouraging distancing from religion is to some extent inherited from the previous social and political period. Many people who declare themselves as non-believers and who are disengaged from the Church have inherited their attitude towards religion from the environment in which they were raised $^{10}$. Such people influence others in their environment as if they are the apostles of religious scepticism and atheism. People who dissociate themselves from religion lack interest in it and are limited to only concerning themselves about the matters of everyday existence ${ }^{11}$.

Proclaiming the word of God, which is a part of pastoral care, is mainly addressed to people who participate in the life of the Church. The forms of proclaiming are addressed to those who attend religious education classes, who participate in religious celebrations and liturgies as well as in other pastoral initiatives which involve the transmission of God's word ${ }^{12}$. Some non-believers or those who are disengaged from religion occasionally participate in some celebrations such as Catholic weddings or funerals. Then they have a chance to hear the Good News. All recipients of the proclamation have a chance to develop their religious knowledge and to confront previously acquired information about religion with the religious message they hear. Receiving information from a source like the Church helps to dispel doubts, to ask new questions about the supernatural reality; it enhances discussion and, for those proclaiming the Word - it makes them able to explain, convince and, above all, present the truth about God, about man and about the world ${ }^{13}$.

Proclaiming God's word is a way of formation for the listeners. God's word has the power to create. It influences its listeners, it shapes their ways of thinking and evaluating, and, as a result, their attitudes. This rule also applies to the truths of faith and the principles of Christian morality which would first be heard and later

\footnotetext{
${ }^{9}$ Witold Kawecki, »Świat mediów areopagiem nowej ewangelizacji, « in Polskie drogi nowej ewangelizacji, ed. Kazimierz Święs, Dariusz Lipiec, (Lublin: Wydawnictwo KUL, 2014), pp. 154-155.

${ }^{10}$ Wiesław Przygoda, »Uwarunkowania historyczno-prawne i eklezjalne ewangelizacji w Polsce po 1989 roku, in Ewangelizacja odpowiedzią Kościoła w Polsce na wyzwania wspótczesności, pp. 63-67.

${ }^{11}$ Robert Biel. »W poszukiwaniu kształtu nowej ewangelizacji $\ll$, in Roczniki Teologiczne, 56 (2014) no. 6, pp. 58-60.

${ }^{12}$ Ryszard Kamiński, Duszpasterstwo w społeczeństwie pluralistycznym, (Lublin: Atla 2), pp. 142-148.

${ }^{13}$ Mirosław Chmielewski, >Catechetical Dimensions of the Homily against the Backround of the 'Homiletic Directory'. Selected Aspects«, in Roczniki Teologiczne, 64 (2017) no. 6, pp. 153-163.
} 
accepted, and which would bring about the inner change in the listeners and their external attitudes ${ }^{14}$.

The listeners of God's word, while accepting its message and following the rules contained therein, build social life and change the conditions of human life according to God's plan. Thus, they become the co-workers of God the Saviour in implementing the saving mission for man and in building God's Kingdom on earth ${ }^{15}$.

However, it must be noted that such proclaiming is limited in its scope. Although pastoral care is missionary and, therefore, open for people who are not members of the Church, it is primarily addressed to the Church community. It is informative and formative for Catholics who are thus confirmed in their faith and in their Christian attitude. It concerns those who are on the outskirts of the Church.

Regarding the limited extent of the influence of proclaiming God's word within the pastoral care ministry, it is necessary to emphasise two important aspects. Those who perceive pastoral care as a way of evangelization, promote the development of evangelization of non-believers and of those who are disengaged from the Church as the mission ad gentes. While those who promote the indispensable re-evangelization in Poland indicate the necessity to broaden the pastoral care ministry within the ordinary pastoral care into new spheres, especially for those who undergo laicization. They also promote an introduction of new forms and methods of proclaiming which would be adjusted to the new type of listeners ${ }^{16}$.

\subsection{Liturgical and Para-liturgical Celebrations}

Liturgy, especially the sacraments, deepen the bonds between believers and between them and God. The Eucharist is a union of man and Christ and it leads to the personal sanctification of man who receives it and permeates his life with the sacred. Therefore, it constitutes the centre of Christian existence and it should shape the personal and social life of those who receive it. Although it is not received with the intention of counteracting laicization in the private sphere of the believer and the secularization of his environment, it plays this role anyway ${ }^{17}$.

${ }^{14}$ Władysław Chaim, »Aspekty psychologiczne w przepowiadaniu słowa Bożego «, in Roczniki Teologiczne, 61 (2014) no. 6, pp. 186-187.

${ }^{15}$ Ryszard Kamiński, Duszpasterstwo w społeczeństwie pluralistycznym, pp. 149-153.

${ }^{16}$ Cf. Krzysztof Pawlina, »Aktualny model ewangelizacji Kościoła w Polsce,« in Ewangelizacja odpowiedzią Kościoła w Polsce na wyzwania wspótczesności, pp. 99-103.

${ }^{17}$ Jan Józef Janicki, »Posługa uświęcania, « in Teologia pastoralna t. 2, ed. Ryszard Kamiński, (Lublin: Atla 2, 2002), pp. 265-270. 
Therefore, we can see the role of other sacraments in a similar way because their main aim is to develop the relationship with God and with other members of the ecclesial community. All sacraments are given to the believers in order to help them develop these relationships in all the important and specific life situations ${ }^{18}$. Unfortunately, many Catholics who receive the sacraments perceive them only in the perspective of their own relationship with God. Those who believe only to a certain extent do not relate the effect of receiving the sacraments to their external, especially social life. Therefore, we can see a discrepancy between faith and social life of believers. Even though they receive the sacraments, they often display attitudes and views contrary to those proclaimed in the Gospel.

Such a situation requires increasing the awareness of believers in connection with the essence and the role of sacraments in the life of a Christian, which should result in rejecting the magical attitude to faith and the ritualism in receiving the sacraments. It seems necessary to properly prepare believers for receiving the sacraments and, in the case of baptism, confirmation and marriage, the preparation should also involve the parents of those who are to receive them. It will later have an influence on the upbringing of young people according to the intention of the received sacraments and help them to accept the consequences of it. One of the most important factors here is learning the Christian style of life which results from being rooted in God's mystery.

Unfortunately, the practice of folk religious customs seems to have more impact on believers. They are perceived by believers as less official, but they are practiced by many of them as well as people who are disengaged from the Church. The influence of customs comes from their closeness to the everyday habits of an average Christian and their expression which evokes emotions that are not observed while receiving sacraments. This feature of traditional devotions usually attracts older Catholics and the younger generation who are attracted by new popular emotional forms of the cult ${ }^{19}$. These include pilgrimages and various pastoral meetings which reflect the Church's approach to the new changing religious needs of contemporary believers. Being »perfectly matched $\ll$ to the needs of contemporary believers as well as attractive expressions of faith, they also attract those Christians, and not only Catholics, who barely participate in the liturgy or pray but who feel the need to stay in touch with or to develop their relationship with God. Participation in such forms of religiousness can be inspiring also for those who are disengaged from the Church and even for non-believers. They direct the mind and emotions

\footnotetext{
${ }^{18}$ Ryszard Kamiński, Działalność zbawcza Kościoła w teorii i praktyce pastoralnej, pp. 263-266.

${ }^{19}$ Ryszard Kamiński, Duszpasterstwo w społeczeństwie pluralistycznym, pp. 178-184.
} 
towards the sphere of the sacred but also make them further engage into the supernatural reality.

Current times have produced various forms of pastoral initiatives which are called the new evangelisation. These are attempts to proclaim the Good News mainly to secular circles, although it is also addressed to believers. They involve events and street performances. They are aimed at introducing Christian contents to the public space and proclaiming the Gospel to people who do not receive the sacraments and who do not attend devotions of God's people. These pastoral initiatives resemble advertisements which are called $\gg$ disturbing adds $\ll$, as their creators make efforts to send a message to people who are not interested in Christian faith, offering them a product in which they are not interested.

The way of making people interested in God and supernatural reality is difficult to accept for many believers. For some believers the receiving of sacraments and living the life of prayer seems childish and superficial. However, for many non-believers, for the doubting or for those disengaged from the Church, it is an innovative and attractive form of proclaiming God and His matters ${ }^{20}$. It breaks many stereotypes concerning religion and believers. The prayer which often accompanies such initiatives is perceived as a dialogue with the living God and not as a monotonous repetition of lines done in order to fulfil a certain duty.

Similarly, proclaiming the word of God as an expression of pastoral care, liturgy and prayer, function as preventive means against secularisation. They are especially characteristic for believers who want to deepen their relationship with God. However, para-liturgical devotions can also have an impact on people who are disengaged from the Church. It is important to acknowledge how important it is to match the form and content of proclaiming to the needs and the possibility of receiving them by the recipients.

\subsection{Implementation of the Pastoral Function}

The pastoral function of the Church consists of the managing function, the charity function and the testimony of Christian life. Its implementation is based on practising Christian love. Within the managing function, the implementation of Christian love is reflected in the service ministry of the Church for the world to which she was sent. The implementation also involves preserving the same nature of the ecclesial offices and ministries. Charity, which can be realized in an organized as well as spontaneous way, is the most noticeable manifestation of Christian love. The

${ }^{20}$ Halina Wrońska, »Modlitwa czynnikiem wspólnoto twórczym katechezy, « in Roczniki Pastoralno-Katechetyczne, 59 (2012), pp. 143-145. 
testimony of Christian life given by believers is the expression of their love for the people around them and of their responsibility for saving others ${ }^{21}$.

Pope Francis emphasizes the menial role of the Church and her pastoral care for the man and for the world. (EG 33) He reminds priests about the necessity to go forth to contemporary people who perceive the Church as an institution rather than as a brotherly community of salvation. Therefore, he promotes simplification of the legal and formal procedures, where it is possible, to prevent the organizational aspect from obscuring the essence and the aim of the ministry ${ }^{22}$.

The menial character of the pastoral ministry of the Church is reflected every time when the Church engages in the social and cultural life, especially locally. Educational and upbringing activities such as running schools, kindergartens, nurseries and day rooms for children and young people or the clubs for adults and senior citizens are perceived in a positive way, as a service to the society. What is more, the Church's engagement in parishes, deaneries or pastoral regional cultural initiatives makes it possible to see the menial character of the Church's ministry to the society in which she exists.

The Church's participation in the community life, especially in local communities, which emphasizes her menial nature, is evangelization. Cooperation with various subjects and people is positive for the mutual acknowledgement and for discovering the values which are the basis of the ministry. Discovering common values between the Church and her partners is of particular importance because it is the basis for the cooperation and for further development of common business. The mutual acknowledgement is also helpful in the process of demythologising the Church and her partners and it can further help to fight against common prejudices.

The dialogue which the Church conducts through pastoral care contributes to the salvation. Cooperation with people and with institutions in various spheres of social life results in evangelization and infusion of the social life with the Christian spirit. As many contemporary communities and institutions are secularized to a great extent, the dialogue of salvation should begin with pre-evangelization in order to cope with any obstacles.

The charitable activity of the Church has a similar meaning. The menial ministry of the Church, perceived as a community and as an institution, is strongly emphasized while Christian love which constitutes the basis of the ministry is even more

${ }^{21}$ Tomasz Wielebski, »Diecezjalne i parafialne struktury komunijne w Polsce, « in Teologia Praktyczna, 13 (2012), pp. 54-55.

${ }^{22}$ Dariusz Lipiec, »Duszpasterstwo misyjne w nauczaniu papieża Franciszka, « in Duszpasterstwo w świetle nauczania papieża Franciszka, ed. Dariusz Lipiec, (Lublin: Wydawnictwo KUL, 2015), pp. 18-21. 
noticeable. The selfless Christian love attracts the attention of the Church's surroundings and prompts questions about the motivation of those who undertake the charitable activities. It directs the attention to the man in need, he becomes the only target of the ministry and his well-being is the most important. In the charitable activity of the Church, the ministry of the Church and her mission are emphasized to the greatest extent.

The example of selfless love is extremely attractive to others, therefore, charity has an apostolic dimension and it contributes to promoting Christianity ${ }^{23}$. The Church does not treat the serving ministry as a tool for implementing other goals. The man in need and his well-being are the centre of this ministry ${ }^{24}$. Although the Church is accused of using charity in an instrumental way, its social impact arises from selflessness. It is this selflessness in the service of man which was the main factor in convincing people for Christianity in the past and it is the factor which helps to attract the attention to the Church today.

The life testimony of the believers can be an important factor in the fight against the secularizing processes ${ }^{25}$. Many believers and the people around the Church pay attention to the life testimony and to the ministry of the clergy and consecrated people $^{26}$. The life testimony of believers is of particular importance in contemporary times. The Second Vatican Council acknowledges their role as the light in the world and as the evangelizing leaven which they are to be in their families and in the society. Many lay people are unaware of their vocation and of the mission and they avoid taking the responsibility which results from their baptism ${ }^{27}$.

\section{Extraordinary Pastoral Care as a Response to the Phenomenon of Secularization}

The extraordinary pastoral care is $\gg$ the saving ministry of the Church which is addressed to certain groups and to those who live in certain environment and who,

\footnotetext{
${ }^{23}$ Wiesław Przygoda, >Apostolski wymiar wolontariatu młodzieży na przykładzie szkolnych kół Caritas, « in Warszawskie Studia Pastoralne, 9 (2014) no. 2, pp. 236-241.

${ }^{24}$ Wiesław Przygoda, »Papieża Franciszka troska pastoralna o ubogich i wykluczonych, « in Duszpasterstwo $w$ świetle nauczania papieża Franciszka, pp. 79-86.

${ }^{25}$ Sławomir Płusa, »Świadectwo w procesie komunikacji wiary, « in Świadectwo w stużbie ewangelizacji, ed. Wiesław Przygoda, (Lublin: Wydawnictwo KUL, 2012), pp. 242-244.

${ }^{26}$ Wiesław Śmigiel, »Świadectwo hierarchii w służbie ewangelizacji, « in Świadectwo w stużbie ewangelizacji, pp. 122-126; Czesław Parzyszek, »Świadectwo życia osób konsekrowanych w służbie nowej ewangelizacji, « in Świadectwo w stużbie ewangelizacji, pp. 158-163.

${ }^{27}$ Marek Fiałkowski, »Świadectwo życia chrześcijańskiego osób świeckich w służbie ewangelizacji,« in Świadectwo w stużbie ewangelizacji, pp. 136-140.
} 
due to their living conditions and their special religious needs, are not able to fully benefit from the ordinary pastoral care $\ll^{28}$. The extraordinary pastoral care has an auxiliary role to the ordinary pastoral care and it complements and inspires it.

In the Polish society which is facing the process of secularization, such branches of extraordinary pastoral care as: the categorical pastoral care, especially the vocational pastoral care and the pastoral care of secular associations, as well as the specialized pastoral care, are more and more important. Social and economic transitions caused changes in the employment structure. As a result, the pastoral care of working people and the pastoral care of farmers have lost their importance, while forms of pastoral care which have never existed or which have had a minor influence, have gained major importance. It concerns such types of pastoral care as: the pastoral care of the tax office, of banking, of the customs, of entrepreneurs and of other professions which are developing, and which are becoming more meaningful in the social and economic life. Being a member of such groups always requires facing challenges and questions concerning the workers' ethos, however, such a set of rules has not been fully developed, particularly in the case of professional ethics. People who work in these professions are not always in a close relationship with God and with the Church, thus becoming a target group for evangelization ${ }^{29}$.

Furthermore, among the major challenges for the pastoral care there are the secular associations. They comprise various clubs, associations, organizations or circles that are not formally associated. They are aimed at organizing free time, relaxing, rest or personal development. The secular associations unite various collectors, athletes and tourists ${ }^{30}$. Such associations consist not only of believers but also people who dissociate themselves from the Church and non-believers. The presence of pastoral care workers among them enables not only the strengthening of the faith of the doubting but also evangelization among the non-believers in these association ${ }^{31}$.

The specialized pastoral care becomes more influential in the contemporary times. It is addressed to people who dissociate themselves from the established social, legal or moral order ${ }^{32}$. The number of such environments is constantly growing,

\footnotetext{
${ }^{28}$ Ryszard Kamiński, »Duszpasterstwo nadzwyczajne, « in: Leksykon teologii pastoralnej, p. 209.

${ }^{29}$ Ryszard Kamiński, Działalność zbawcza Kościoła w teorii i praktyce pastoralnej, pp. 294-296.

${ }^{30}$ Maciej Ostrowski, »Czas wolny - zagrożenie czy szansa formacji wiary?,« in Duszpasterstwo wobec kryzysu wiary, ed. Wiesław Przygoda, Kazimierz Święs, (Lublin: Wydawnictwo KUL, 2013), pp. 349-351.

${ }^{31}$ Jan Wal, »Apostolat środowiskowy chrześcijan, « in Teologia pastoralna t.2, pp. 277-279.

${ }^{32}$ Marek Fiałkowski, »'Dziedziniec pogan' miejscem dialogu z niewierzącymi, « in Peryferie wiary wyzwaniem dla Kościoła, ed. Wiesław Przygoda, Marek Fiałkowski, (Lublin: Wydawnictwo KUL, 2015), pp. 104-106.
} 
and they are more and more varied. Their most common feature is the denial of the presence of sacred in the life of an individual as well as in the social life, which relates to the rejection of various social values ${ }^{33}$. The presence of such people prompts taking actions not only towards the people who have long been the target of the specialized pastoral care such as prisoners or addicts, but also towards the members of new movements or subcultures. These new movements, which mainly associate young people, are very dynamic and, therefore, they are a challenge for the pastoral care that must react immediately and work out new methods not used before. Since new movements and subcultures have a greater social impact, they have become an even greater challenge for the pastoral care ${ }^{34}$.

\section{Ending}

Fighting the currents of new secularization is not the main aim of pastoral care and of the Church. It is mostly aimed at the faithful and the churchgoers in order to help them strengthen and develop their faith. Therefore, pastoral care has a preventive role, preventing the secularization of Christians and their environment. Taking into account the fact that pastoral care is a missionary and evangelizing activity, it is also addressed to those who are in the environment of Catholics and it tries to influence them through the word of God which they hear, through the prayer they say and through the testimony of Christian love.

The extraordinary pastoral care has an even more important role to play as it is addressed mainly to those who are not able to make use of the forms offered by the ordinary pastoral care. Its aim is to complement the ordinary pastoral care. It is also addressed to those who are on the outskirts of the Church, therefore, the extraordinary pastoral care plays a particular role here.

\footnotetext{
${ }^{33}$ Ryszard Kamiński, Działalność zbawcza Kościoła w teorii i praktyce pastoralnej, pp. 297-298.

${ }^{34}$ Marek Fiałkowski, »Ruchy religijne jako miejsce i narzędzie nawrócenia, « in Duszpasterstwo wświetle nauczania papieża Franciszka, pp. 131-133.
} 


\title{
PASTORALNA SKRB KAO ODGOVOR CRKVE NA FENOMEN SEKULARIZACIJE
}

\author{
Dariusz LIPIEC*
}

Sažetak: U tijeku je proces sekularizacije europskih društava koji je prisutan već nekoliko desetljeća. Veliki je to izazov za Crkvu koja mu se nastoji oduprijeti na različite načine. Pastoralna skrb, zamišljena kao organizirana spasenjska djelatnost Crkve kojoj je cilj spasenje čovjeka, jedan je od takvih načina. Medutim, opiranje procesu sekularizacije nije izravan cilj pastoralne skrbi. Ukoliko se pastoralna skrb provodi na pravilan način, ona može biti moćno i smisleno sredstvo Crkve u opiranju laicizaciji. U članku su predstavljeni različiti oblici redovite i izvanredne pastoralne skrbi koji doprinose razvoju religioznosti vjernika i širenju Evanđelja u zajedničkom društvenom životu. Najprije, autor predstavlja ulogu redovite pastoralne skrbi u ovom procesu. Zatim nabraja: naviještanje Božje riječi, različite oblike kulta i služenje kršćanske ljubavi kao načine oživljavanja vjerskog života. Također ukazuje na ulogu izvanredne pastoralne skrbi, posebice one vrste koja smjera na suradnju s novim radnickim udruživanjima koja se razvijaju $i$ s drugim neformalnim svjetovnim udruženjima.

Ključne riječi: Crkva, sekularizacija, laicizacija, pastoralna skrb, redovita pastoralna skrb, izvanredna pastoralna skrb.

* Prof. dr. sc. Dariusz Lipiec, Katoličko sveučilište Ivana Pavla II. u Lublinu, Al. Racławickie 14, 20950 Lublin, Poljska, dlipiec@kul.pl 